\title{
Frontline Demonstrations of Capsicum, Turmeric, Garlic and Chilli in District Rupnagar in Sub-mountainous Zone of Punjab
}

\author{
Sanjeev Ahuja*, Opinder Singh and G.S. Makkar \\ Krishi Viygan Kendra, Haveli Kalan, Ropar, India \\ *Corresponding author
}

\section{A B S T R A C T}

\begin{tabular}{|l|}
\hline Key w o r d s \\
Frontline \\
demonstrations, \\
Extension gap, \\
Capsicum, \\
Turmeric, Garlic, \\
Chilli, Technology \\
index, Yield \\
\hline Article Info \\
\hline $\begin{array}{l}\text { Accepted: } \\
\text { 22 June } 2020 \\
\text { Available Online: } \\
\text { 10 July 2020 }\end{array}$ \\
\hline
\end{tabular}

\section{Introduction}

Vegetables occupy major place in terms of area, production and productivity in India, Punjab and district Rupnagar. They contribute major share to GDP in the country. The area under vegetables is 102.59 lakh ha with production of 1843.94 lakh ton in India (2017-18). The area under spices is 254.3 lakh ha and production of 3117.14 lakh ton(201718) in India.
In Punjab the vegetables were grown in an area of 103.64 thousand ha with production of 4.77 thousand ton. The capsicum crop was grown in 0.36 thousand ha area with production of 5.71 thousand ton, The capsicum crop was grown in the 0.36 thousand ha area with production of 5.71 thousand ton, the carrot crop was grown in 8.87 thousand ha area with production of 197.17 thousand ton, the chilli crop was grown in 8.21 thousand ha area with production of 15.54 thousand ton, 
while the tomato crop was grown in 9.01 thousand ha area with production of 224.26 thousand ton, garlic crop was grown in 6.46 thousand ha area with production of 73.70 thousand ton, garlic crop was grown in 6.46 thousand ha area with production of 73.70 thousand ton, turmeric crop was grown in 0.90 thousand ha area with production of 3.90 thousand ton, brinjal was grown in 21.71 thousand ha area with production of 22.91 thousand ton. Here in Punjab, the value of Rs. 687179 vegetables are produced (2015-16).

In case of district Rupnagar the area, production and productivity of major crops during the year 2017-18 is as follows. In terms of area, potato ranks seventh, onion eighth, cauliflower ninth, while tomato ranks tenth. In the district, the production of onion is 4.58 lakh ton from an area of 0.208 thousand ha with productivity of 1192 metric ton per ha. Tomato crop has production of 3.009 lakh ton from an area of 0.13 thousand ha with productivity of 1247 metric ton per ha. The brinjal crop has production of 1.94 lakh ton from an area of 0.091 thousand ha with productivity of 756 metric ton per ha. The vegetables are rich source of vitamins, minerals and essential nutrients required for good health of human being. So, vegetables are economically important crops. They may be grown in varied environmental condition except harsh climatic conditions and on most of the soils. Better management practices in terms of nutrient management, weed management, intercultural operations, insect pest and disease management could be translated to higher yields. The frontline demonstrations (FLDs) were conducted in five blocks of the district Rupnagar by Krishi Vigyan Kendra, Roparto improve the vegetable yield levels and create awareness among farmers. In the present study, improved varieties of vegetables recommended by PAU, Ludhiana were compared with the most common varieties grown by the vegetable growers by using the farmers cultivation practices and evaluated in front line demonstrations conducted at farmer's fields from 2017 to 2020. The farmers varieties were compared with recommended varieties by following the recommended package of cultivation practices. The vegetables grown in the front line demonstrations were capsicum, turmeric, garlic and chilli.

\section{Material and Methods}

The present study was carried out by the KrishiVigyan Kendra, Haveli Kalan, Ropar The frontline demonstrations wred conducted over an area of 8 acres om the five blocks of district Ropar, i.e., Ropar, Nurpurbedi, Sri Anandpur Sahib, Chamkaur Sahib and Morinda. Five farmers were selected from each block with an area of one 0.25 acre each. The planting of capsicum and chilli were done in the first week of October, while turmeric crop planted in the last week of April and first week of May and garlic in the second week of October. The frontline demonstrations were conducted to study the gap between potential yield, demonstration yield, extension gap and technology index. An area of 0.1 acre was also sown alongside the FLD and was managed by farmers without following PAU recommended practices. The scientist from KVK provided timely guidance to the farmers on weed control, fertilizer requirement, and insect-pest and disease management. Technology gap, extension gap and technology index were calculated using the standard procedure (Samui et al., 2000)

\section{Results and Discussion}

\section{Yield performance}

The results of front line demonstration reveled that average yield of 225, 325, 138 and $250 \mathrm{q} /$ ha (Table 1) was obtained in 
Ropar, Nurpurbedi, Sri Anandpur Sahib, Chamkaur Sahib and Morinda blocks of district Ropar during the year 2017-2020, respectively. The yield was found to be 29 , 53, 59.5 and 25 per cent higher over the farmer's practice in the Ropar, Nurpurbedi, Sri Anandpur Sahib, Chamkaur Sahib and Morinda blocks of district Rupnagar, respectively, this increase clearly indicates the positive impact of frontline demonstrations on the vegetables yield.

\section{Technology gap}

The technology is the yield gap between vegetables yield under frontline demonstrations and vegetable yield by following the farmer practices. It also reflects the farmers cooperation in carrying out such demonstration.

The technology gap of $0.6,0.15,0.2$ and $0.3 \mathrm{q}$ per ha was observed in Ropar, Nurpurbedi, Sri Anandpur Sahib, Chamkaur Sahib and Morinda blocks of district Ropar, Respectively (Table-1). The technology gap observed may be attributed to variability in the management practices, soil fertility, fertilizer application, wee, insect- pest and disease control and climatic conditions.

The extension gap of 2.5, 1.9, 1.2 and $0.8 \mathrm{q}$ per ha was observed in Ropar, Nurpurbedi, Sri Anandpur Sahib, Chamkaur Sahib and Morinda blocks of district Ropar, respectively, highlighted the need to educate the farmers through varion means for the adoption of improved agricultural technologies.

The higher adoption of recent production technology with high yielding varieties, better weed, insect pest and disease management, the irrigation and fertilizer application technologies would subsequently change this alarming trend galloping the extension gap.

\section{Technology index}

The feasibility of the improved technology at the farmer's field is indicated through technology index. The lowest values of technology index indicate the more feasibility of the technology index from 55 to 77 per cent indicated that the demonstrated technologies were feasible in improve the yield of the vegetables (Table 1).

\section{Benefit Cost Ratio}

The benefit to cost ratio (B:C) from using recommended practice were comparatively higher than the farmer's practices of the demonstration (Table 2. The return per ha from the frontline demonstrations were higher than that of farmer practices. The range of benefit cost ratio of frontline demonstration of varied from 7.0 to 9.0 , while $\mathrm{BC}$ ratio for farmers practices varied from 5.5 to 4.1 that is lower than that of FLDs.

In conclusion, the results of front line demonstration convincingly brought out that the yield of vegetables could be increased by 68.3, 45.4, 35.8, 56.5 and 62.4 er cent higher over the farmers practice in the Roar, Nururbedi, Sri Anandur Sahib Chamkaur Sahib and Morinda blocks of district Ropar, Respectively. This study clearly reflects the extension and technological gap exist at grass root level.

The increase in yield clearly indicates the positive impact of better management practices followed in the front line demonstrations on the vegetables yield. Thus, it could also be concluded that e better management interventions for the cultivation reduce the extension and technology gap to great extent. This would sustainably increase the income as well as the livelihood of the farmer of this district. 
Table.1 Productivity, Technology gap, extension gap and technology index of vegetable crops under FLDs and Farmer's field

\begin{tabular}{|c|c|c|c|c|c|c|c|c|c|c|c|c|c|c|c|}
\hline Block & $\begin{array}{l}\text { Capsicum } \\
\text { FLD } \\
\text { Average } \\
\text { Yield } \\
\text { (q/ha) }\end{array}$ & $\begin{array}{l}\text { Turmeric } \\
\text { FLD } \\
\text { Average } \\
\text { Yield } \\
\text { (q/ha }\end{array}$ & $\begin{array}{l}\text { Garlic } \\
\text { FLD } \\
\text { Average } \\
\text { Yield } \\
\text { (q/ha) }\end{array}$ & $\begin{array}{l}\text { Chilli } \\
\text { FLD } \\
\text { Average } \\
\text { Yield } \\
\text { (q/ha }\end{array}$ & $\begin{array}{l}\text { Capsicum } \\
\text { Farmer's } \\
\text { Practice } \\
\text { (q/ha) }\end{array}$ & $\begin{array}{l}\text { Turmeric } \\
\text { Farmer's } \\
\text { Practice } \\
\text { (q/ha) }\end{array}$ & $\begin{array}{l}\text { Garlic } \\
\text { Farmer's } \\
\text { Practice } \\
\text { (q/ha) }\end{array}$ & $\begin{array}{l}\text { Chilli } \\
\text { Farmer's } \\
\text { Practice } \\
\text { (q/ha) }\end{array}$ & $\begin{array}{l}\text { Per cent } \\
\text { Increased } \\
\text { yield } \\
\text { (Capsicum) }\end{array}$ & $\begin{array}{l}\text { Per cent } \\
\text { Increased } \\
\text { yield } \\
\text { (Turmeric) }\end{array}$ & $\begin{array}{l}\text { Per cent } \\
\text { Increased } \\
\text { yield } \\
\text { (Garlic) }\end{array}$ & $\begin{array}{l}\text { Per cent } \\
\text { Increased } \\
\text { yield } \\
\text { (Chilli) }\end{array}$ & $\begin{array}{l}\text { Technology } \\
\text { gap }\end{array}$ & $\begin{array}{l}\text { Extension } \\
\text { gap }\end{array}$ & $\begin{array}{l}\text { Technology } \\
\text { index }(\%)\end{array}$ \\
\hline Ropar & 225 & 325 & 138 & 250 & 175 & 213 & 105 & 200 & 28.6 & 52.6 & 31.4 & 25.1 & 0.6 & 2.5 & 54 \\
\hline Nurpurbedi & 235 & 321 & 139 & 248 & 181 & 210 & 108 & 197 & 15.8 & 52.8 & 28.7 & 25.9 & 0.15 & 1.9 & 57 \\
\hline $\begin{array}{l}\text { Sri } \\
\text { Anandpur } \\
\text { Sahib }\end{array}$ & 215 & 318 & 143 & 247 & 186 & 216 & 110 & 194 & 15.4 & 47.2 & 30.1 & 27.3 & 0.2 & 1.2 & 68 \\
\hline $\begin{array}{l}\text { Sri } \\
\text { Chamkaur } \\
\text { Sahib }\end{array}$ & 220 & 328 & 141 & 253 & 170 & 219 & 101 & 203 & 16.8 & 49.8 & 39.6 & 24.6 & 0.3 & 0.8 & 72 \\
\hline Morinda & 240 & 331 & 137 & 257 & 167 & 209 & 103 & 206 & 17.1 & 58.4 & 33.1 & 24.7 & & & 77 \\
\hline
\end{tabular}

Table.2 Economic impact of vegetable crops under FLDs and Farmer's practices

\begin{tabular}{|c|c|c|c|c|c|c|}
\hline Block & $\begin{array}{c}\text { Cost of cultivation } \\
\text { (Rs./ha) }\end{array}$ & $\begin{array}{l}\text { Cost of cultivation } \\
\text { (Rs./ha) }\end{array}$ & $\begin{array}{c}\text { Gross } \\
\text { Returns } \\
\text { (Rs./ha) }\end{array}$ & $\begin{array}{l}\text { Gross Returns } \\
\text { (Rs./ha) }\end{array}$ & B:C Ratio & B:C Ratio \\
\hline & FLD & Farmer's practice & FLD & $\begin{array}{l}\text { Farmer's } \\
\text { practice }\end{array}$ & FLD & $\begin{array}{c}\text { Farmer's } \\
\text { practice }\end{array}$ \\
\hline Ropar & 64350 & 67350 & 223000 & 194000 & 4.1 & 2.7 \\
\hline Nurpurbedi & 60100 & 69400 & 227000 & 197000 & 3.8 & 2.8 \\
\hline $\begin{array}{l}\text { Sri Anandpur } \\
\text { Sahib }\end{array}$ & 65600 & 70250 & 236000 & 198000 & 4.1 & 2.9 \\
\hline $\begin{array}{l}\text { Sri Chamkaur } \\
\text { Sahib }\end{array}$ & 68300 & 72500 & 241000 & 185000 & 3.7 & 2.1 \\
\hline Morinda & 65450 & 66700 & 243000 & 191000 & 3.1 & 2.3 \\
\hline
\end{tabular}


Table.3The different parameters recorded for Capsicum crop

\begin{tabular}{|l|c|c|c|c|c|}
\hline $\begin{array}{l}\text { Capsicum } \\
\text { Demonstration } \\
\text { Yield (q/ha) }\end{array}$ & $\begin{array}{c}\text { Farmer's } \\
\text { Practice } \\
\text { (q/ha) }\end{array}$ & $\begin{array}{c}\text { Per cent } \\
\text { Increased yield } \\
\text { (Capsicum) }\end{array}$ & Technology gap & Extension gap & $\begin{array}{c}\text { Technology } \\
\text { index }(\mathbf{\%})\end{array}$ \\
\hline $\mathbf{2 2 5}$ & 175 & 28.6 & 0.6 & 2.5 & 54 \\
\hline $\mathbf{2 3 5}$ & 181 & 15.8 & 0.15 & 1.9 & 57 \\
\hline $\mathbf{2 1 5}$ & 186 & 15.4 & 0.2 & 1.2 & 68 \\
\hline $\mathbf{2 2 0}$ & 170 & 16.8 & 0.3 & 0.8 & 72 \\
\hline $\mathbf{2 4 0}$ & 167 & 17.1 & 0.25 & 0.7 & 77 \\
\hline
\end{tabular}

Table.4 The different parameters recorded for Turmeric crop

\begin{tabular}{|l|c|c|c|c|c|}
\hline $\begin{array}{l}\text { Turmeric Demonstration } \\
\text { Average Yield (q/ha) }\end{array}$ & $\begin{array}{c}\text { Farmer's } \\
\text { Practice (q/ha) }\end{array}$ & $\begin{array}{c}\text { Per cent Increased } \\
\text { yield (Capsicum) }\end{array}$ & $\begin{array}{c}\text { Technology } \\
\text { gap }\end{array}$ & $\begin{array}{c}\text { Extension } \\
\text { gap }\end{array}$ & $\begin{array}{c}\text { Technology } \\
\text { index (\%) }\end{array}$ \\
\hline $\mathbf{3 2 5}$ & 213 & 52.6 & 0.5 & 2.8 & 58 \\
\hline $\mathbf{3 2 1}$ & 210 & 52.8 & 0.3 & 2.0 & 61 \\
\hline $\mathbf{3 1 8}$ & 216 & 47.2 & 0.2 & 1.4 & 73 \\
\hline $\mathbf{3 2 8}$ & 219 & 49.8 & 0.4 & 0.9 & 77 \\
\hline $\mathbf{3 3 1}$ & 167 & 58.4 & 0.35 & 1.3 & 75 \\
\hline
\end{tabular}

Table.5 The different parameters recorded for Garlic crop

\begin{tabular}{|l|c|c|c|c|c|}
\hline $\begin{array}{l}\text { Garlic FLD Demonstration } \\
\text { Yield (q/ha) }\end{array}$ & $\begin{array}{c}\text { Farmer's Practice } \\
(\mathbf{q} / \mathbf{h a})\end{array}$ & $\begin{array}{c}\text { Per cent Increased } \\
\text { yield (Capsicum) }\end{array}$ & $\begin{array}{c}\text { Technology } \\
\text { gap }\end{array}$ & $\begin{array}{c}\text { Extension gap } \\
\text { Technology } \\
\text { index (\%) }\end{array}$ \\
\hline $\mathbf{1 3 8}$ & 105 & 31.4 & 0.3 & 3.1 & 61 \\
\hline $\mathbf{1 3 9}$ & 108 & 28.7 & 0.5 & 2.4 & 64 \\
\hline $\mathbf{1 4 3}$ & 110 & 30.1 & 0.3 & 1.2 & 71 \\
\hline $\mathbf{1 4 1}$ & 101 & 39.6 & 0.45 & 0.7 & 76 \\
\hline $\mathbf{1 3 7}$ & 103 & 33.1 & 0.2 & 1.1 \\
\hline
\end{tabular}


Table.6 The different parameters recorded for Chilli crop

\begin{tabular}{|l|c|c|c|c|c|}
\hline $\begin{array}{l}\text { Chilli } \\
\text { demonstration } \\
\text { average yield } \\
\text { (q/ha) }\end{array}$ & $\begin{array}{c}\text { Farmer's } \\
\text { Practice } \\
\text { (q/ha) }\end{array}$ & $\begin{array}{c}\text { Per cent } \\
\text { Increased yield } \\
\text { (Capsicum) }\end{array}$ & Technology gap & Extension gap & $\begin{array}{c}\text { Technology } \\
\text { index (\%) }\end{array}$ \\
\hline $\mathbf{2 5 0}$ & 200 & 25.1 & 0.2 & 2.9 & 63 \\
\hline $\mathbf{2 4 8}$ & 197 & 25.9 & 0.7 & 3.1 & 57 \\
\hline $\mathbf{2 4 7}$ & 194 & 27.3 & 0.2 & 1.5 & 73 \\
\hline $\mathbf{2 5 3}$ & 203 & 24.6 & 0.5 & 1.2 & 75 \\
\hline $\mathbf{2 5 7}$ & 206 & 24.7 & 0.15 & 0.9 & 77 \\
\hline
\end{tabular}

Table.7 Technology interventions under demonstration plots and farmers practices

\begin{tabular}{|c|c|c|}
\hline Parameters & Demonstration & Farmer's Practice \\
\hline Variety & $\begin{array}{l}\text { Bharat (Capsicum), Punjab Haldi-2 (Turmeric), } \\
\text { PG-17 (Garlic) and CH-27 (Chilli) }\end{array}$ & Local variety \\
\hline Seed Rate & $\begin{array}{l}250 \mathrm{~g} \mathrm{ha}^{-1} \text { (Capsicum), } 15 \mathrm{q} \mathrm{ha}^{-1} \text { (Turmeric), } 7.5 \\
\mathrm{q} \mathrm{ha}^{-1}\left(\text { Garlic) and } 500 \mathrm{~g} \mathrm{ha}^{-1} \text { (Chilli) }\right.\end{array}$ & $\begin{array}{l}300 \mathrm{~g} \mathrm{ha}^{-1} \text { (Capsicum), } 17 \mathrm{q} \mathrm{ha}^{-1} \\
\text { (Turmeric), } 9.0 \mathrm{q} \mathrm{ha}^{-1} \text { (Garlic) and } \\
400 \mathrm{~g} \mathrm{ha}^{-1} \text { (Chilli) }\end{array}$ \\
\hline Seed Treatment & Seed treatment with fungicide & No seed treatment \\
\hline Time of sowing & $\begin{array}{l}\text { Mid October (Capsicum), Ist week of May } \\
\text { (Turmeric), Ist week of October (Garlic) and Ist } \\
\text { week of November (Chilli) }\end{array}$ & Same as for Demonstration \\
\hline Method of sowing & $\begin{array}{l}\text { Transplanting for Capsicum and Chilli and } \\
\text { planting for Turmeric and Garlic }\end{array}$ & Same as for Demonstration \\
\hline $\begin{array}{l}\text { Plant protection } \\
\text { measures }\end{array}$ & $\begin{array}{l}\text { Need based application of pesticides as } \\
\text { recommended by PAU, Ludhiana }\end{array}$ & Blanket application of pesticides \\
\hline Fertilizer application & Recommended fertilizer application & Blanket fertilizer application \\
\hline Weed Management & Use of recommended weedicides & $\begin{array}{l}\text { Use of recommended and } \\
\text { unrecommended weedicides }\end{array}$ \\
\hline
\end{tabular}




\section{References}

Balai C.M., Jalwania, R., Verma L.N., Bairwa R. K., and Regar P.C. (2013) Economic impact of Front Line Demonstrations on Vegetables in Tribal Belt of Rajasthan. Current Agriculture Research Journal.

Dudek, S.G. 2001, Nutitionsessientials for nusing practice. Philadelphia: Lippincott.

Gaharwar Anjali M, UghadeJayashri D (2018) Impact analysis study of front line demonstrations regarding integrated cultivation technology for onion var. Akola Safed. Journal of Pharmacognosy and Phytochemistry. 7(6): 1351-1354.

Katiyar H., Verma S.K., Singh K, Chandra N., and Lodhi S.K. (2017) Yield gap analysis in vegetable crops through on farm testing. Journal of Pharmacognosy and Phytochemistry. SP1: 773-775

Painkra G.P., Salam D.C., and Mishra R.K. (2012) Role of front line demonstrations on yield enhancement of different crops in Sarguja district of Chhatishgarh. Crop Research. Print ISSN: 0970-4884. Samui, S. K,,Mitra, S., Roy, D.K., Mandal, A, K \&Saha, D. 2000 Evalusation of front line demonstration on groundnut. Jounal of the Indian Society Costal Agriculture Research 18(2): 180-183.

Singh, S. N., Singh, V. K., Singh, R. K., and Rakesh K. S., 2007 Evaluation of OnFarm Front Line Demonstrations on the Yield of Mustard in Central Plains Zone of Uttar Pradesh. Indian Res. J. Ext. Edu. 7 (2\&3).

\section{How to cite this article:}

Sanjeev Ahuja, Opinder Singh and Makkar, G.S. 2020. Frontline Demonstrations of Capsicum, Turmeric, Garlic and Chilli in District Rupnagar in Sub-mountainous Zone of Punjab. Int.J.Curr.Microbiol.App.Sci. 9(07): 3690-3696. doi: https://doi.org/10.20546/ijcmas.2020.907.432 